\title{
Recent variations in surface mass balance of the Antarctic Peninsula ice sheet
}

\author{
Elizabeth M. MORRIS, ${ }^{*}$ Robert MULVANEY \\ British Antarctic Survey, Natural Environment Research Council, Madingley Road, Cambridge CB3 OET, England \\ E-mail:emmo@nerc-bas.ac.uk
}

\begin{abstract}
Over the period 1972-98 the height of the snow surface at eight Antarctic sites in Palmer Land and on Alexander Island has been measured with respect to fixed points on local nunataks. From these data an empirical relation between height changes over a given period and three key variables has been derived. These variables are (i) the local mean annual surface air temperature, (ii) a regional estimate of energy available for melt over the period (derived from the nearby Rothera air-temperature record) and (iii) a regional estimate of accumulation over the period (derived from the nearby Gomez Nunatak ice-core accumulation record). Using this relation, the contribution of the Antarctic Peninsula to sea-level rise for warming from climatic conditions (averaged over the last 30 years) is estimated to be $-0.006 \pm 0.002 \mathrm{~mm} \mathrm{a}^{-1} \mathrm{~K}^{-1}$. If recent warm conditions persist, however, and meltwater can run off to the sea, the contribution to sea-level rise from ablation is calculated to be $0.07 \pm 0.02 \mathrm{~mm} \mathrm{a}^{-1} \mathrm{~K}^{-1}$.
\end{abstract}

\section{INTRODUCTION}

Major climate-related changes have been observed in the Antarctic Peninsula area over the second half of the 20th century. King (1994) reports increases in near-surface air temperature, and Turner and others (1997) report a rise in the number of precipitation events from research stations. Peel (1992) reports that ice cores from the region show an increase in accumulation at higher elevations. On the other hand, observations of glacier retreat (Smith and others, 1998) and reduction of snow cover at low elevations (Fox and Cooper, 1998) indicate increased summer melt. All these data suggest that surface mass balance has been responding to local climate change, but the data are sparse, especially in the southern part of the peninsula.

Measurements of changes in surface height, by satellite, airborne or ground-based instruments, can be used to estimate mass balance over a wider area. However, they need to be interpreted with care. Supporting data such as surface air temperature, snow density and accumulation rate are required. In this paper, we first use local data from ground surveys in the Antarctic Peninsula to elucidate the relationship between surface height and mass balance and then proceed to derive regional relationships. Using these relationships, we then estimate the change in mass balance for the climate changes expected over the next century and the consequent contribution of the Antarctic Peninsula to sealevel rise.

From 1975 to 1986 a series of glacier profiles in Palmer Land and Alexander Island were measured by the British Antarctic Survey in an attempt to monitor the effect of climate change on the volume of ice in different areas of the Antarctic Peninsula (Fig. 1).When the profiles were established, the only

* Present address: Scott Polar Research Institute, Lensfield Road, Cambridge CB2 1ER, England. accurate means of determining glacier surface height as a function of distance along a fixed line was by optical levelling between benchmarks on rock at each end of the line. Hence all the lines run between nunataks and are relatively short $\left(0.5^{-}\right.$ $2.5 \mathrm{~km}$ long). This paper describes the results of re-surveys of the profiles over the period 1992-98 using both traditional and global positioning system (GPS) satellite techniques.

Some of the data have been reported previously (Morris and Mulvaney, 1996; Morris, 1999), but the completion of a new survey in Moraine Corrie in 1998, the acquisition of recent meteorological data and the completion of two studies on the spatial variation of accumulation and $10 \mathrm{~m}$ temperature over the Antarctic Peninsula have prompted this analysis which leads to a significant change in our 1995 estimate of sensitivity of the Antarctic Peninsula to climate warming.

\section{THE FIELD SURVEY}

Table 1 lists the lines and the dates on which they were surveyed by various parties. The lines were marked out with stakes using a theodolite. Before 1992 the profiles were determined by levelling and theodolite tacheometry. From 1992 onwards, two dual-frequency Trimble 4000SSE geodetic GPS systems were also used to (a) establish the geographical coordinates of a benchmark (BM) on each line with respect to the World Geodetic System 1984 ellipsoidal elevation(WGS84) ellipsoid by point positioning and (b) determine the height with respect to the $\mathrm{BM}$ along each line by differential surveying. Whenever the terrain allowed, a kinematic technique was used, with one static antenna and the other mounted on a snowmobile travelling along the line at approximately $20 \mathrm{~m}$ per $15 \mathrm{~s}$ epoch. Antenna swaps were undertaken at the start and finish of each kinematic survey. Broadcast epheremides were used in processing the GPS data and, since the distances between receivers were always $<5 \mathrm{~km}$, ionospheric corrections were not made. 


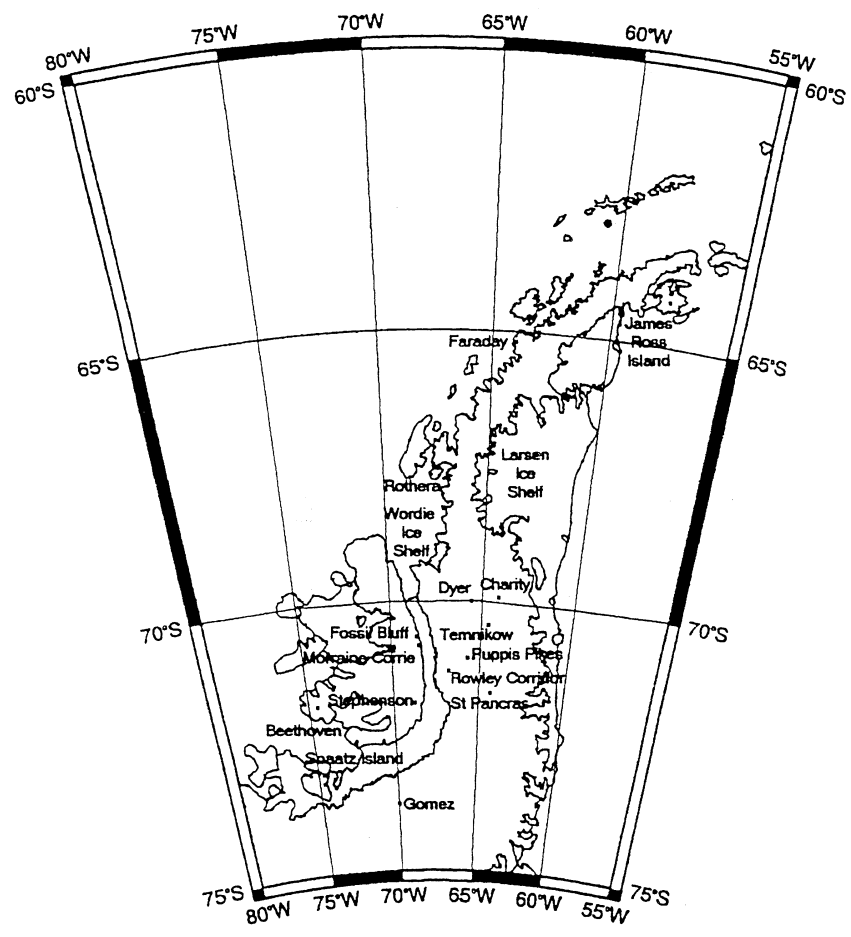

Fig. 1. Map of the Antarctic Peninsula showing places referred to in the text.

Ice cores were collected near, but not on, each line to avoid disturbing the ground. The borehole temperature, $T_{\mathrm{b}}$, was measured at least 12 hours and normally $>20$ hours after drilling was completed. Density profiles were determined by weighing ice-core segments $(10-20 \mathrm{~cm}$ long) before they were subdivided into samples for chemical analysis. Near the surface, if the snow was too unconsolidated to give good cores, samples were collected from the wall of a snow pit. The mean annual surface temperature, $T_{\mathrm{m}}$, was estimated from the borehole temperature using the nomogram described by Morris and Vaughan (1994). This method of estimating mean annual temperature is based on the assumption that there is no summer melting. Inspection of the cores shows evidence of some melting at Stephenson Nunatak and considerable melting at Rowley Corridor. For these two sites, the mean annual temperature is probably slightly warmer than that estimated from the borehole data.

\section{Puppis Pikes}

The profile runs from the northeastern outcrop of Puppis Pikes, where the southwest benchmark (SWBM) is established on a small rock ridge, towards the northwestern outcrop of the southeastern nunatak of Carina Heights (Fig. 2). Over the $700 \mathrm{~m}$ that were surveyed twice in 1993 the average difference in height was $-0.023 \pm 0.043 \mathrm{~m}$. (The range quoted is the standard deviation of the measurements, not the standard error in the mean, since the differences are not samples from a population with constant mean). This difference can be used as an estimate of the error that can arise from slight differences in the path taken along a line on repeat survey. Since the first $700 \mathrm{~m}$ of the line are relatively steep, this estimate is probably higher than necessary for the flatter, lower parts of the profile.

Since the lines have been chosen to run from benchmarks on exposed rock, it is clear that any height differences will decrease to zero at the benchmarks. In order to determine a representative height difference, we therefore aver-

Table 1. The Antarctic Peninsula profiles

\begin{tabular}{|c|c|c|c|c|c|c|c|c|}
\hline Site & Benchmark & Position & $\begin{array}{l}T_{\mathrm{b}} \\
{ }^{\circ} \mathrm{C}\end{array}$ & $\begin{array}{l}T_{\mathrm{m}} \\
{ }^{\circ} \mathrm{C}\end{array}$ & $D / m$ & Survey dates & Surveyor & Source \\
\hline Charity & SWBM & $\begin{array}{c}69^{\circ} 58^{\prime} 52.58^{\prime \prime} \mathrm{S} \\
64^{\circ} 13^{\prime} 50.80^{\prime \prime} \mathrm{W} \\
(1990 \text { ma.e. })\end{array}$ & -19.45 & -18.1 & 6.60 & $\begin{array}{c}\text { 16 Jan } 1986 \\
\text { 16,19 Dec } 1992\end{array}$ & $\begin{array}{l}\text { Richardson } \\
\text { Morris }\end{array}$ & $\begin{array}{l}\text { Richardson (1986) } \\
\text { Morris (1994) }\end{array}$ \\
\hline Puppis Pikes & SWBM & $\begin{array}{c}71^{\circ} 13^{\prime} 51.47^{\prime \prime} \mathrm{S} \\
66^{\circ} 8^{\prime} 33.68^{\prime \prime} \mathrm{W} \\
\text { (1356 m a.e. })\end{array}$ & -15.42 & -15.2 & 10.52 & $\begin{array}{c}\text { 30 Jan-3 Feb } 1986 \\
\text { 5 Jan } 1993\end{array}$ & $\begin{array}{c}\text { Richardson } \\
\text { Morris }\end{array}$ & $\begin{array}{c}\text { Richardson (1986) } \\
\text { Morris and Mulvaney (1995) }\end{array}$ \\
\hline Rowley Corridor & WBM & $\begin{array}{c}71^{\circ} 30^{\prime} 43.77^{\prime \prime} \mathrm{S} \\
67^{\circ} 17^{\prime} 37.95^{\prime \prime} \mathrm{W} \\
(471 \mathrm{~m} \text { a.e. })\end{array}$ & -9.64 & -9.0 & 6.86 & $\begin{array}{c}15 \text { Feb } 1976 \\
\text { 15-20 Feb } 1986 \\
\text { 12-14 Jan } 1993\end{array}$ & $\begin{array}{c}\text { Lennon } \\
\text { Richardson } \\
\text { Morris }\end{array}$ & $\begin{array}{c}\text { Lennon (1976) } \\
\text { Richardson (1986) } \\
\text { Morris (1994) }\end{array}$ \\
\hline St Pancras & SWBM & $\begin{array}{c}71^{\circ} 44^{\prime} 34.72^{\prime \prime} \mathrm{S} \\
63^{\circ} 59^{\prime} 46.66^{\prime \prime} \mathrm{W} \\
\text { (1861 ma.e. })\end{array}$ & -19.91 & -19.5 & 9.29 & $\begin{array}{c}\text { 6 Jan } 1986 \\
\text { 22 Jan } 1993\end{array}$ & $\begin{array}{l}\text { Richardson } \\
\text { Morris }\end{array}$ & $\begin{array}{l}\text { Richardson (1986) } \\
\text { Morris (1994) }\end{array}$ \\
\hline Stephenson & NBM & $\begin{array}{c}72^{\circ} 00^{\prime} 2.30^{\prime \prime} \mathrm{S} \\
69^{\circ} 05^{\prime} 21.46^{\prime \prime} \mathrm{W} \\
(537 \text { m a.e. })\end{array}$ & -11.86 & -11.6 & 10.21 & $\begin{array}{l}30 \text { Dec } 1985 \\
11-12 \text { Feb } 1993\end{array}$ & $\begin{array}{l}\text { Richardson } \\
\text { Morris }\end{array}$ & $\begin{array}{l}\text { Richardson (1986) } \\
\text { Morris (1994) }\end{array}$ \\
\hline Moraine Corrie & $\mathrm{BM}$ & $\begin{array}{c}71^{\circ} 19^{\prime} 32.44^{\prime \prime} \mathrm{S} \\
68^{\circ} 17^{\prime} 12.66^{\prime \prime} \mathrm{W} \\
(68.9 \text { m a.e. })\end{array}$ & & & & $\begin{array}{c}\text { 30 Sept } 1972 \\
\text { 27-28 Feb } 1986 \\
27 \text { Feb-1 Mar } 1993 \\
\text { 25/26 Feb } 1995 \\
\text { 18/20 Feb } 1998\end{array}$ & $\begin{array}{l}\text { Pearson and Rose } \\
\text { Richardson } \\
\text { Morris } \\
\text { Morris } \\
\text { Morris }\end{array}$ & $\begin{array}{c}\text { Richardson (1986) } \\
\text { Richardson (1986) } \\
\text { Morris and Mulvaney (1995) } \\
\text { Morris (1999) }\end{array}$ \\
\hline
\end{tabular}





Fig. 2. Puppis Pikes profiles. (a) Profiles from 1986 ( o ) with cubic-spline fit and from 1993 (+). (b) Change in level from 1986 to 1993 (solid line) and between successive surveys in 1993 (broken line). The arrow indicates the core site, and the bar shows the range over which the height differences are averaged.

age over the middle of the line, $700-1600 \mathrm{~m}$ from the SWBM, away from the steep slopes at the beginning and end. Between 1986 and 1992 the mean height difference over this lower part of the profile was $0.60 \pm 0.10 \mathrm{~m}$. This is significantly greater than the estimated error in repeat measurements. Assuming that any rock uplift during the period is either negligibly small or constant over the level line, the equivalent ice-sheet thickening rate is $0.087 \pm 0.014 \mathrm{~m} \mathrm{a}^{-1}$.

\section{Temnikow}

The profile lies between two of this small group of nunataks situated in a wide open bowl 20-30 km across. A bergschrund crosses the line near the north benchmark (NBM), and the last $25 \mathrm{~m}$ of the line near the south benchmark (SBM) are very steep and icy (Fig. 3). Between 1975 and 1980 the mean height difference over the lower part of the profile, 100$350 \mathrm{~m}$ from the NBM, was $-0.07 \pm 0.15 \mathrm{~m}$. This is equivalent to a thickening rate of $-0.014 \pm 0.03 \mathrm{~m} \mathrm{a}^{-1}$. From 1980 to 1986 the height change over the same range was $0.14 \pm 0.15 \mathrm{~m}$, equivalent to $0.023 \pm 0.015 \mathrm{~m} \mathrm{a}^{-1}$. Finally, from 1986 to 1992 the height change was $-0.22 \pm 0.27 \mathrm{~m}$ and the equivalent thickening rate $-0.037 \pm 0.046 \mathrm{~m} \mathrm{a}^{-1}$.

\section{St Pancras}

The profile runs between the two easternmost nunataks of the Gutenko Mountains in a wide, open, flat area on the
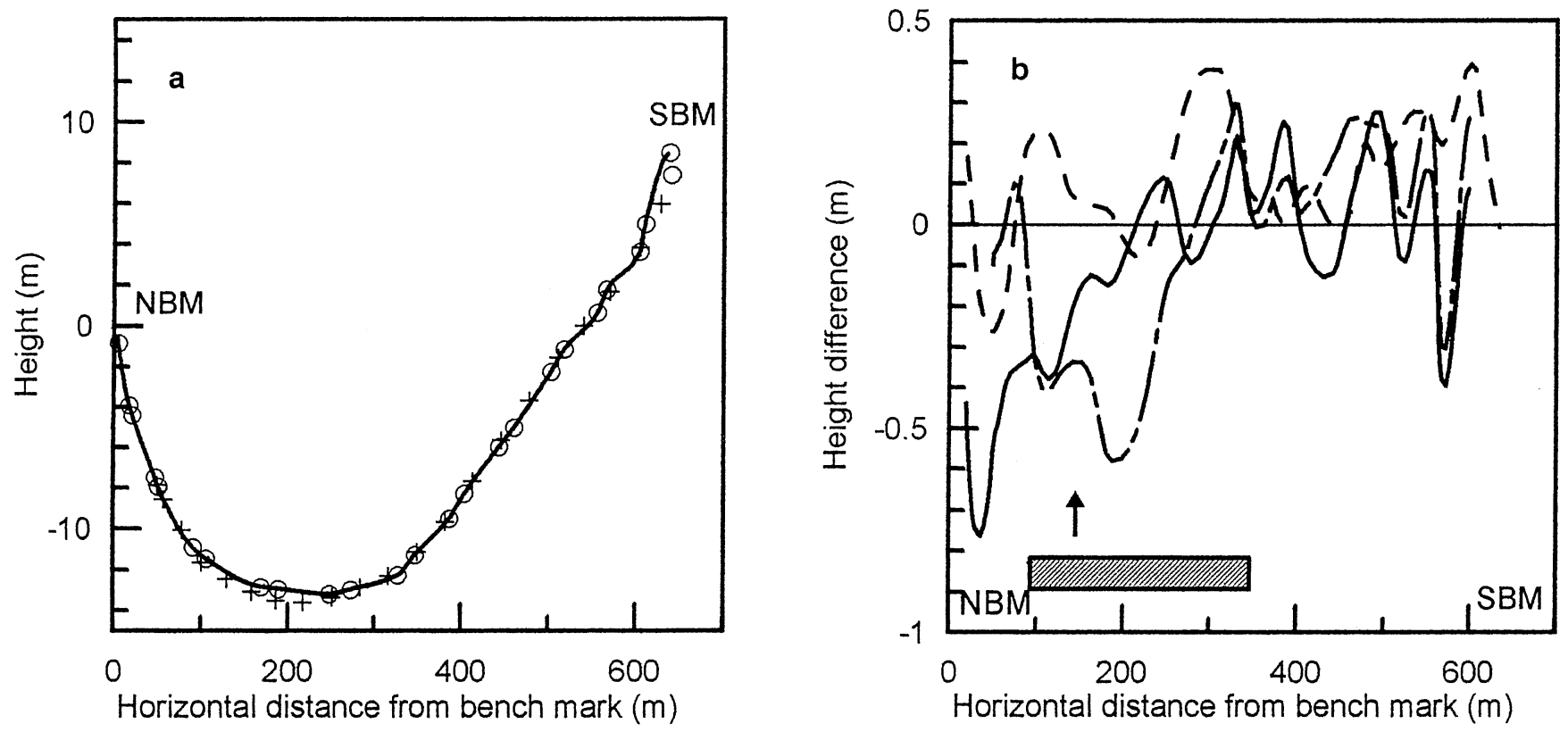

Fig. 3. Temnikow profiles. (a) Profiles from 1986 ( o ) with cubic-spline fit and from 1992 (+). (b) Changes in level from 1975 to 1980 (solid line), 1980 to 1986 (dashed line) and 1986 to 1992 (dot-dash line). The arrow indicates the core site, and the bar shows the range over which the height differences are averaged. 

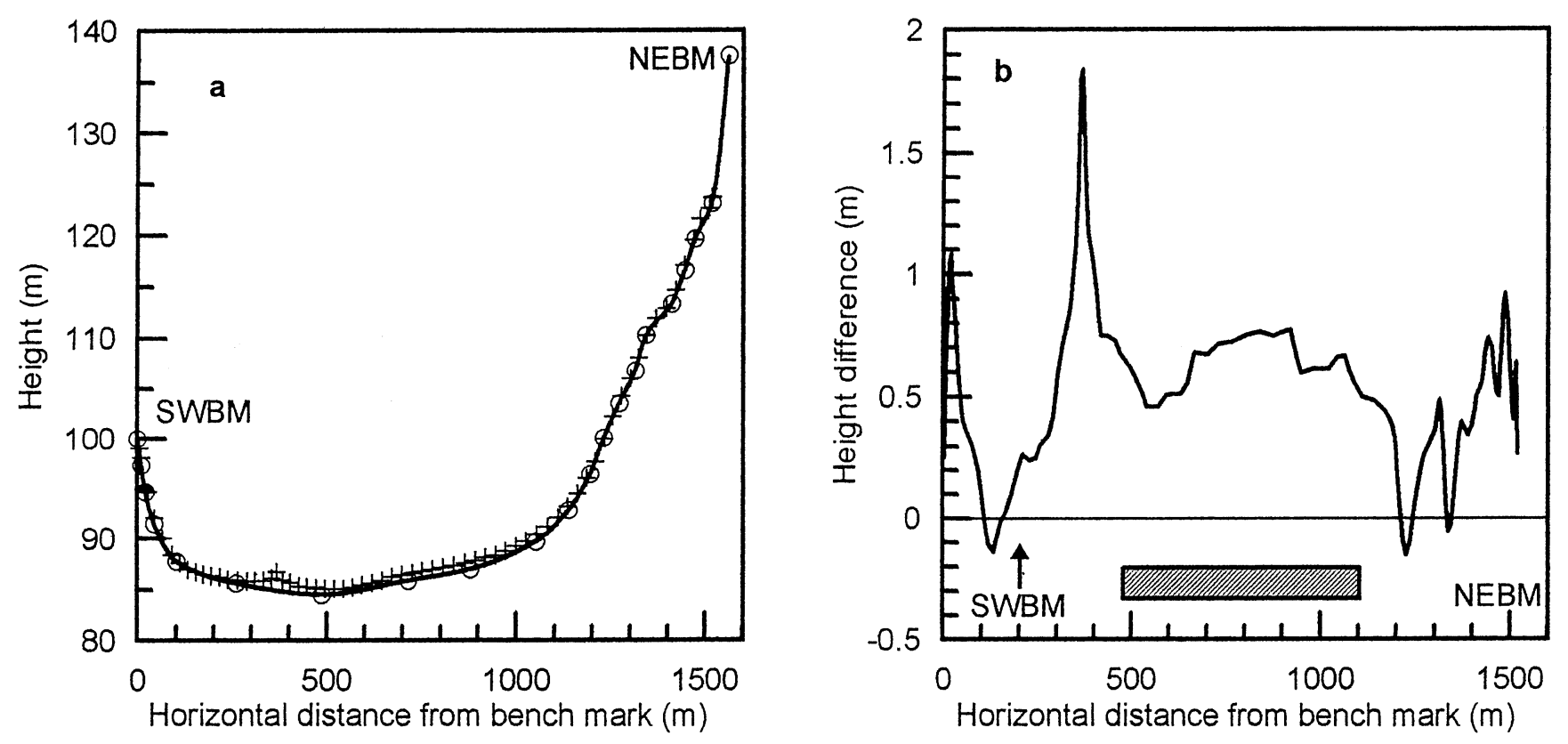

Fig. 4. St Pancras profiles. (a) Profiles from 1986 ( o ) with cubic-spline fit and from 1993 (+). (b) Change in level from 1986 to 1993. The arrow indicates the core site, and the bar shows the range over which the height differences are averaged.

crest of the Antarctic Peninsula plateau. Some $400 \mathrm{~m}$ from the SWBM along the profile, there is a rock hump exposed in patches. It has wind tails to southeast and northwest i.e. perpendicular to the line (Fig. 4). The rock hump is not mentioned by Richardson (1986). It can be assumed that the 1986 profile is inaccurate around $400 \mathrm{~m}$ from the SWBM since the levelling legs were too long and the rock hump was missed in the survey. However, at the lowest point of the line, at around $500 \mathrm{~m}$ from the SWBM, both profiles can be assumed to be accurate. The difference in height over the range $500-1100 \mathrm{~m}$ from the SWBM is $0.61 \pm 0.10 \mathrm{~m}$, equivalent to a thickening rate of $0.087 \pm 0.014 \mathrm{~m} \mathrm{a}^{-1}$.

\section{Charity}

The Charity profile lies between two nunataks which lie on



a ridge running parallel to the Eternity Range some $8 \mathrm{~km}$ to the northwest. At the time of the resurvey in 1992, the surface snow was about $20 \mathrm{~cm}$ deep and carved into sastrugi. However, the ends of the profile, near the SWBM and northeast benchmark (NEBM), were swept bare of snow and showed clear blue ice (Fig. 5).

Because of the terrain, levelling data were supplemented by a combination of static and Stop-and-Go kinematic satellite surveying on foot. The four points established in the Stop-and-Go survey agree with the levelled points, bearing in mind the presence of sastrugi up to $20 \mathrm{~cm}$ deep over the middle portion of the line. Figure $5 \mathrm{~b}$ shows the difference between cubic spline curves fitted to the 1992 and 1986 points. The oscillation in the difference curve arises from the sparsity of the measurements and is most obvious for the steep region in the first $150 \mathrm{~m}$ from the SWBM.

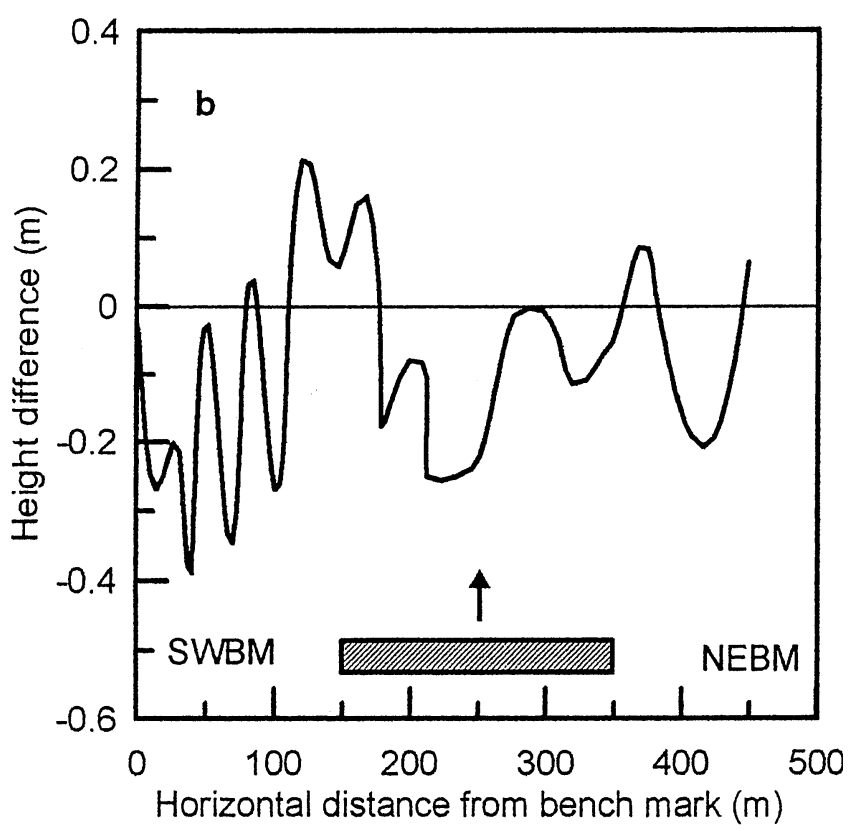

Fig. 5. Charity profiles. (a) Profiles from 1986 ( o ) with cubic-spline fit and from 1992 (+). (b) Change in level from 1986 to 1992. The arrow indicates the core site, and the bar shows the range over which the height differences are averaged. 

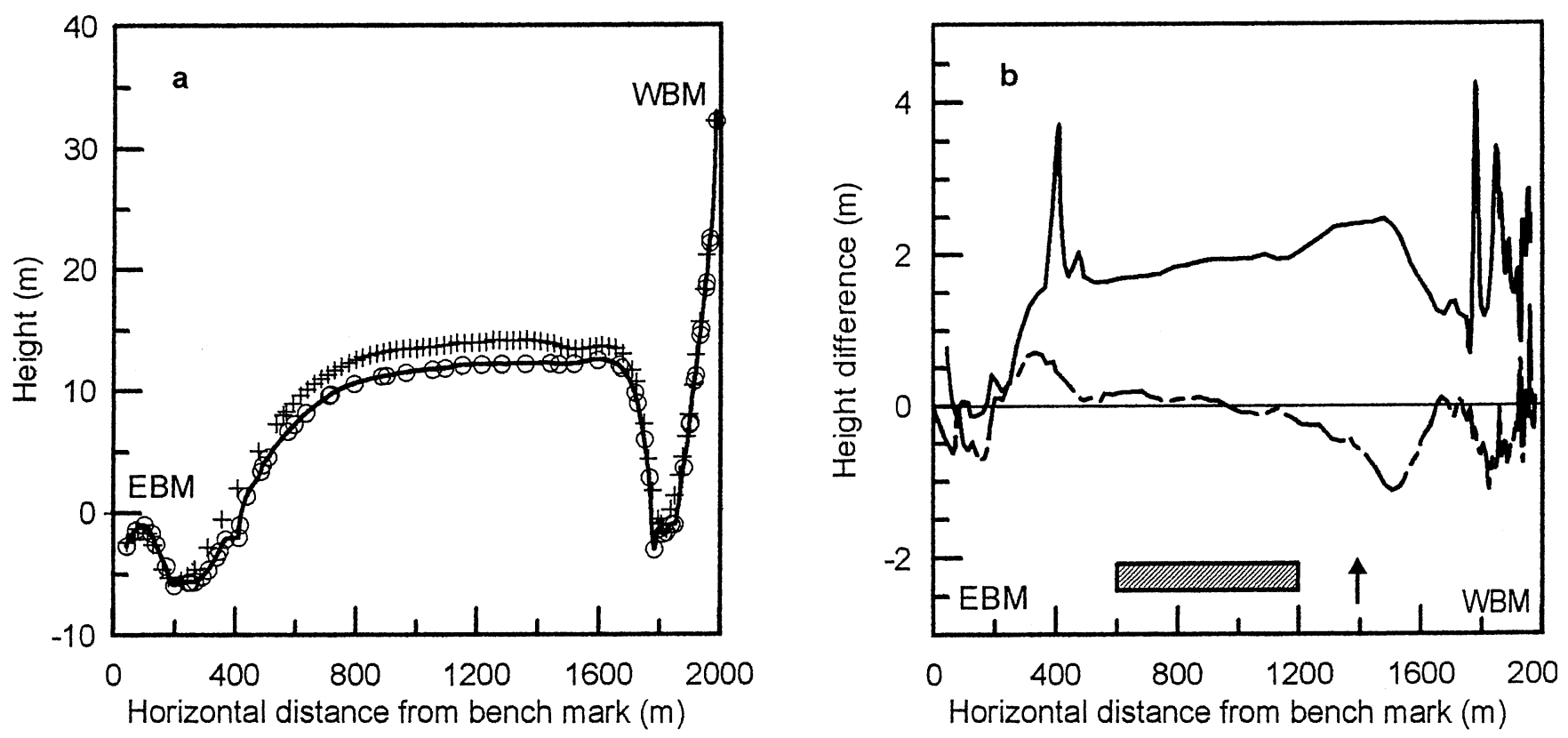

Fig. 6. Rowley Corridor profiles. (a) Profiles from 1976 ( o) with cubic-spline fit and from 1993 (+). (b) Changes in level from 1976 to 1986 (solid line) and from 1986 to 1993 (dashed line). The arrow indicates the core site, and the bar showes the range over which the height differences are averaged.

Averaging over the middle part of the profile, from 150 to $350 \mathrm{~m}$, gives a mean height difference of $-0.08 \pm 0.12 \mathrm{~m}$. This is equivalent to a thickening rate of $-0.012 \pm$ $0.017 \mathrm{ma}^{-1}$.

\section{Rowley Corridor}

The profile lies in a $6 \mathrm{~km}$ section of an ice-filled valley (the Rowley Corridor) connecting Conchie and Armstrong Glaciers which drain ice from the Antarctic Peninsula plateau into the George VI Ice Shelf. Both these glaciers are heavily crevassed, but the section of the Rowley Corridor between them is free of crevasses. The ice is presumed to flow slowly towards Conchie Glacier (Richardson, 1986).

In 1993, kinematic satellite surveying was used over the

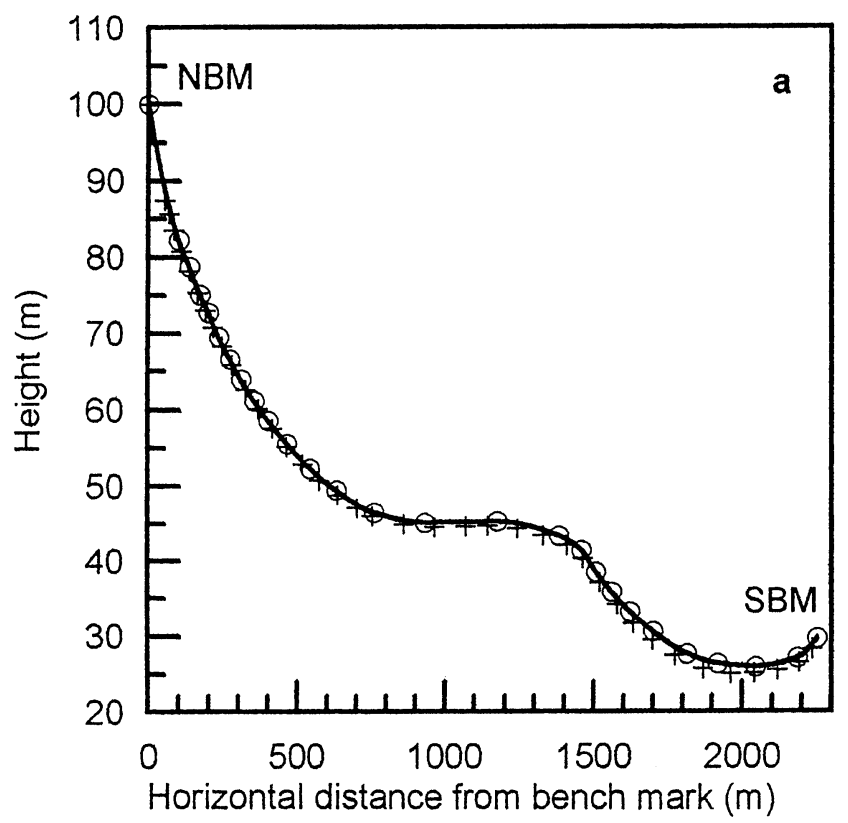

central part of the line, and a combination of static satellite surveying and levelling on the steep, overshadowed side sections (Fig. 6). The profile begins at the top of the snow scoop near the EBM. There is then a minimum where moraine brought in from the south edge of a small cirque glacier $200 \mathrm{~m}$ north of the profile lies on the surface of the ice. The smaller rocks melt into the ice, and this process seems to have reduced the level of this area by about $0.5 \mathrm{~m}$ from 1986 to 1993 . The next minimum marks the point where ice from the north edge of the cirque glacier meets ice from further up the Rowley Corridor. About $1500 \mathrm{~m}$ from the EBM there is another dip in the 1993 profile. This does not appear in the 1986 data, although there are signs of it in the 1976 profile. The last minimum in the profile marks the side of the glacier. In 1993 the valley was deeper than in 1986,

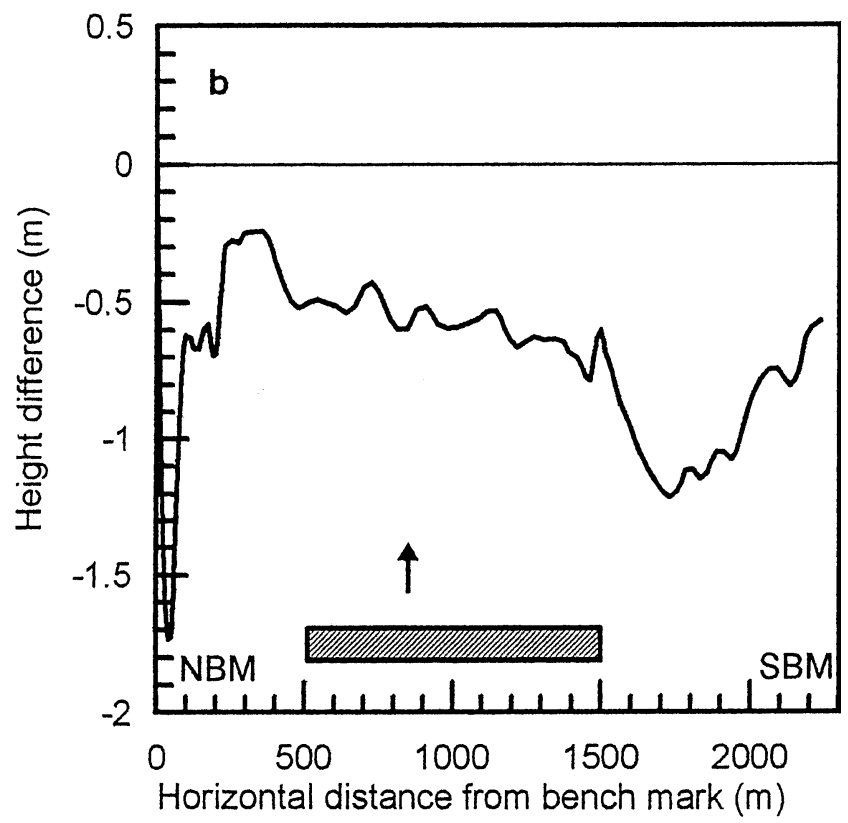

Fig. 7. Stephenson Nunatak profiles. (a) Profiles from 1986 ( o) with cubic-spline fit and from 1993 (+). (b) Change in level from 1986 to 1993. The arrow indicates the core site, and the bar shows the range over which the height differences are averaged. 

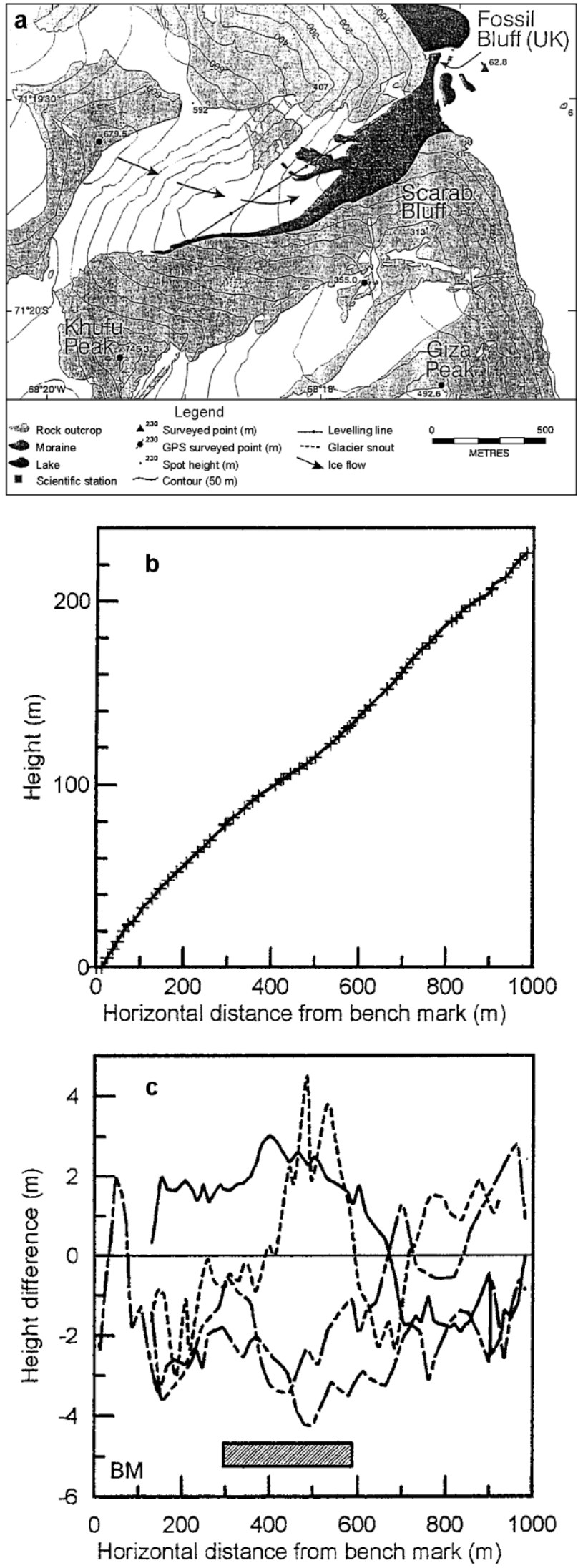

Fig. 8. (a) Map of Moraine Corrie Glacier showing the level line. (b) Profile of the glacier from 1993 (+) with cubicspline fit. (c) Changes in level from 1972 to 1986 (dashed line), 1986 to 1993 (dot-dash line), 1993 to 1995 (solid line) and 1995 to 1998 (dot-dot-dash line). The bar shows the range over which the height differences are averaged.

probably because of the meltstream since Richardson does not mention such a feature. The slope up to the WBM was as in 1986. Over the range $600-1200 \mathrm{~m}$ the height difference from 1976 to 1986 was $1.87 \pm 0.10 \mathrm{~m}$, equivalent to a thick- ening rate of $0.187 \pm 0.010 \mathrm{~m} \mathrm{a}^{-1}$. From 1986 to 1993 the height difference was $0.03 \pm 0.11$, equivalent to $0.004 \pm 0.014 \mathrm{ma}^{-1}$.

\section{Stephenson}

The Stephenson profile runs north-south between two nunataks $15 \mathrm{~km}$ north of Stephenson Nunatak (Fig. 7). For most of the line there is no cross-slope. The area is open and flat, although the overall ice-flow direction is probably southeast towards George VI Sound. The surfaces show no signs of meltstream formations, although fossil streams are apparent at a slightly lower altitude a few kilometres to the southeast.

One of the GPS receivers failed during the 1993 survey and it was therefore necessary to revert to levelling. Over the flat central part of the line, 500-1500 m from the SBM, the height difference was $-0.58 \pm 0.08 \mathrm{~m}$, equivalent to a thickening rate of $-0.082 \pm 0.011 \mathrm{~m} \mathrm{a}^{-1}$.

\section{Moraine Corrie}

The profile runs from a BM near an ice-cored moraine about $100 \mathrm{~m}$ in front of the steep snout of Moraine Corrie Glacier. It crosses the glacier at an angle to the direction of flow and ends on the crest of the southern lateral moraine (Fig. 8). The surface of the glacier is extremely rough, with penitents up to $1 \mathrm{~m}$ high, boulder tables, meltwater streams $20 \mathrm{~cm}$ wide and a general covering of rock debris so the albedo is low even after a new snowfall. It is enclosed between high rock walls which reflect radiation back onto the glacier and is sheltered from wind.

The 1993 survey was made using theodolite tacheometry in poor conditions (Morris and Mulvaney, 1996), and conditions were even more difficult for the 1995 survey as sudden drainage of the proglacial lake had produced a massive collapse of the ice shelf in front of Moraine Corrie, cutting off easy access to the BM (Morris, 1999). However, in 1998 it was possible to survey the profile using static satellite surveying.

In some places the 1986 level is higher than the 1972 level, in others, lower. The 1993 level is generally lower than the 1986 level. However, the period 1993-95 shows a thickening of the lower part of the line and a thinning upstream. This behaviour is reversed over the period 1995-98. Clearly both dynamic and surface mass-balance changes are involved. We have chosen to determine mean height change over the middle part of the glacier 300-600 $\mathrm{m}$ from the BM away from the sides of the glacier. The height differences are $1.25 \pm 1.60 \mathrm{~m}$ for $1972-86, \quad-3.02 \pm 0.71 \mathrm{~m}$ for $1986-93$, $2.19 \pm 0.46 \mathrm{~m}$ for $1993-95$ and $-2.10 \pm 0.91 \mathrm{~m}$ for $1995-98$. The equivalent thickening rates are $0.15 \pm 0.19,-0.43 \pm 0.10$, $1.10 \pm 0.23$ and $-0.71 \pm 0.31 \mathrm{~m} \mathrm{a}^{-1}$.

\section{ANALYSIS}

The first step in the analysis is to relate the change in surface height at a given site to changes in accumulation rate and surface air temperature at the same site, that is, to derive local relationships.

Local accumulation series at some of the profile sites have been determined directly from measurement of isotopic ratios in the ice cores collected in 1992/93. Table 2 shows the annual accumulation series, $a_{t}$, for Puppis Pikes, Temnikow, St Pancras, Rowley Corridor and Stephenson 


\begin{tabular}{|c|c|c|c|c|c|}
\hline & $\begin{array}{l}\text { Puppis Pikes } \\
\text { m w.e. } \mathrm{a}^{-1}\end{array}$ & $\begin{array}{l}\text { Stephenson } \\
\text { m w.e. } \mathrm{a}^{-1}\end{array}$ & $\begin{array}{c}\text { Site } \\
\text { St Pancras } \\
\text { m w.e. } \mathrm{a}^{-1}\end{array}$ & $\begin{array}{l}\text { Rowley Corridor } \\
\text { m w.e. } \mathrm{a}^{-1}\end{array}$ & $\begin{array}{c}\text { Temnikow (1995 core) } \\
\text { m w.e. } \mathrm{a}^{-1}\end{array}$ \\
\hline $\begin{array}{c}a_{t} \\
\text { July 1993-July } 1994 \\
\text { July 1992-July } 1993 \\
\\
\text { July } 1991-\text { July } 1992 \\
\text { July 1990-July } 1991 \\
\text { July 1989-July } 1990 \\
\text { July 1988-July } 1989 \\
\text { July 1987-July } 1988 \\
\text { July 1986-July } 1987 \\
\text { July 1985-July } 1986 \\
\text { July 1984-July } 1985 \\
\text { July 1983-July } 1984 \\
\text { July 1982-July } 1983 \\
\text { July 1981-July } 1982 \\
\text { July 1980-July } 1981\end{array}$ & $\begin{array}{c}0.157 \\
(6 \text { months) } \\
0.630 \\
0.423 \\
0.420 \\
0.252 \\
0.376 \\
0.441 \\
0.359 \\
0.268 \\
0.415 \\
0.271 \\
0.307 \\
0.616\end{array}$ & 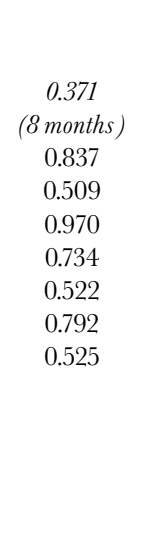 & $\begin{array}{c}0.243 \\
(8 \text { months) } \\
0.202 \\
0.253 \\
0.511 \\
0.450 \\
0.457 \\
0.206 \\
0.197 \\
0.311 \\
0.312 \\
0.659 \\
0.809\end{array}$ & $\begin{array}{c}0.473 \\
(7 \text { months) } \\
0.791 \\
0.622 \\
0.940 \\
0.920 \\
1.001\end{array}$ & $\begin{array}{l}0.158 \\
0.328 \\
\\
0.245 \\
0.255 \\
0.266 \\
0.249 \\
0.276 \\
0.227 \\
0.261 \\
0.257\end{array}$ \\
\hline $\begin{array}{l}\text { Mean value } a^{*} \\
\text { Standard error in mean } \sigma_{\mathrm{m}} \\
\text { Standard deviation } \sigma \\
\text { Range } R \\
\text { Hurst's } k \\
\text { Number of years between } \\
\text { min. and max. storage } N\end{array}$ & $\begin{array}{c}0.398 \\
0.036 \\
0.119 \\
0.495 \\
0.797 \\
8\end{array}$ & $\begin{array}{c}0.698 \\
0.069 \\
0.169 \\
0.308 \\
0.479 \\
-2\end{array}$ & $\begin{array}{c}0.397 \\
0.061 \\
0.193 \\
0.674 \\
0.734 \\
9\end{array}$ & $\begin{array}{c}0.855 \\
0.068 \\
0.135 \\
0.297 \\
0.860 \\
2\end{array}$ & $\begin{array}{c}0.252 \\
0.013 \\
0.040 \\
0.107 \\
0.608 \\
6\end{array}$ \\
\hline
\end{tabular}

Nunatak, and the mean annual accumulation, $a^{*}$, over the period covered by the core. Strictly, $a_{t}$ are the water equivalents between successive isotopic minima which appear when the temperature is coldest, normally in July. Defining $\bar{a}$ as the mean long-term outflow across a fixed lower boundary, the water equivalent storage in year $n$ above this boundary is

$$
S_{n}=\sum_{t=1}^{n}(a-\bar{a})(1 \text { year })+S_{0},
$$

where $S_{0}$ is the initial storage. The range $R$ is defined as the difference between maximum and minimum values of the storage. The values of $R$ and Hurst's $k$ (Hurst and others, 1965) for the accumulation series given in Table 2 have been calculated using $a^{*}$ as an estimate for $\bar{a}$. If the two are not equal (and we have no evidence to tell us whether the sites are in long-term balance or not), $R$ will be overestimated by $\left(a^{*}-\bar{a}\right) N$, where $N$ is the number of years between minimum and maximum storage.

The next step is to determine the effective density which is needed to relate changes in mass storage to changes in surface height. For dry snow, Wingham (2000) shows that over short periods the effective density can be taken to be that of the new snow at the surface, $\rho_{\mathrm{ns}}$. Using the short-term mean accumulation $a^{*} \pm \sigma_{\mathrm{m}}$ as an estimate for the mean outflow over the period, the change in height $\Delta h$ over the time period $t_{1}-t_{2}$ can be written

$$
\Delta h \approx \frac{S\left(t_{2}\right)-S\left(t_{1}\right)}{\rho_{\mathrm{ns}}} \pm\left(\frac{1}{\rho_{\mathrm{i}}}-\frac{1}{\rho_{\mathrm{ns}}}\right)\left(t_{2}-t_{1}\right) \sigma_{\mathrm{m}},
$$

where $\rho_{\mathrm{i}}=917 \mathrm{~kg} \mathrm{~m}^{-3}$ is the density of ice. Table 3 shows the measured values of $\Delta h$ and the values calculated using Equation (2). The surface density has been set to $\rho_{\mathrm{ns}}=350 \mathrm{~kg} \mathrm{~m}^{-3}$ on the basis of the observed densities. Because the accumulation series for Rowley Corridor is too short to determine $S\left(t_{1}\right)$, the range $R$ has been used as an estimate for $S\left(t_{2}\right)-S\left(t_{1}\right)$ in this case. The measured and calculated values of $\Delta h$ agree to their respective uncertainties, except for the St Pancras profile. The disagreement in this case could indicate that the accumulation series derived from isotopic analysis of the core is inaccurate or that the mean accumulation from the series is not a good estimate for the mean outflow, i.e. a dynamic effect.

It is also possible to estimate the mean outflow more directly by installing stakes anchored deep in the firn and measuring their downward velocity (Hamilton and others, 1998). This would be a useful additional measurement to make in future work and would enable any imbalance between inflow and outflow to be detected.

The ice-core density profiles are useful as an indicator of the extent of summer melting at each site. The warm sites (Rowley Corridor and Stephenson Nunatak) show pronounced ice layering, whereas at the coldest sites (St Pancras and Charity) no layers were found. Clearly the expression relating height change to accumulation for dry

Table 3. Change in height at profile sites from 1986 to 1992/93 calculated from the accumulation record

\begin{tabular}{lcc}
\hline Site & $\begin{array}{c}\text { Measured height } \\
\text { increase }\end{array}$ & $\begin{array}{c}\text { Calculated height } \\
\text { increase }\end{array}$ \\
& $\mathrm{m}$ & $\mathrm{m}$ \\
\hline Puppis Pikes & $0.60 \pm 0.10$ & $0.38 \pm 0.44$ \\
Temnikow & $0.22 \pm 0.27$ & $0.12 \pm 0.14$ \\
St Pancras & $0.61 \pm 0.10$ & $-1.07 \pm 0.75$ \\
Stevenson & $-0.58 \pm 0.08$ & $0.28 \pm 0.86$ \\
Rowley Corridor & $0.03 \pm 0.11$ & $-0.85 \pm 0.94$ \\
& & \\
\hline
\end{tabular}


snow (Equation (2)) has to be modified to take account of density changes related to local temperature. The only local temperature available for our sites is the borehole temperature. If the surface air temperature remains below $0^{\circ} \mathrm{C}$ throughout the year, a good estimate of the average mean annual surface temperature $T_{\mathrm{m}}$ over the past few years can be obtained from the borehole temperature, $T_{\mathrm{b}}$. For warmer areas $T_{\mathrm{b}}$ is likely to be colder than $T_{\mathrm{m}}$.

We begin the analysis of local relationships by looking at the spatial variation of water equivalent thickening rate, $\Theta=\Delta h \rho_{\mathrm{s}} / \rho_{\mathrm{w}} \Delta t$, over the period $\Delta t=t_{2}-t_{1}$ to determine the effect of local temperature on the response of the profiles. Table 4 shows the water equivalent thickening rates for all the sites and periods. The surface density is $\rho_{\mathrm{s}}=350 \mathrm{~kg} \mathrm{~m}^{-3}$ except for Moraine Corrie where the value for ice $\rho_{\mathrm{i}}=917 \mathrm{~kg} \mathrm{~m}^{-3}$ is used.

The number of sites is not sufficient to deduce any very complex expression to describe the spatial variation of water equivalent thickening rate. We therefore investigate whether any simple link to the spatial variation of mean annual temperature can be made. Figure 9 shows the water equivalent thickening rates for all sites except Moraine Corrie for the period 1986-92/3 as a function of $T_{\mathrm{m}}$. A linear relation fitted to all the data shows a decrease in $\theta$ with increasing mean annual temperature. This is as expected: at warmer temperatures the accumulation is transformed to denser snow and the associated height change is reduced. However, since $r^{2}=0.15$ this result is not significant. We can make further progress by dividing the sites into two groups: (1) St Pancras, Rowley Corridor and Puppis Pikes and (2) Charity, Temnikow and Stephenson. The gradients of the lines shown are (1) $\quad-0.0029 \pm 0.0014 \mathrm{mw}$.e. $\mathrm{a}^{-1} \mathrm{~K}^{-1}$ and (2) $-0.00318 \pm 0.00021 \mathrm{~m}$ w.e. $\mathrm{a}^{-1} \mathrm{~K}^{-1}$ and the correlations are now high with $r^{2}=0.81$ and $r^{2}=0.99$ respectively.

It is reasonable to assume a common gradient of $-0.003 \mathrm{~m}$ w.e. $\mathrm{a}^{-1} \mathrm{~K}^{-1}$ for both groups since this is essentially a parameter which describes a physical process which depends on temperature, not on geographical position per se. This leaves the intercepts at $T_{\mathrm{m}}=0^{\circ} \mathrm{C}$ to distinguish the groups. These are $\theta_{0}=-0.023 \pm 0.022 \mathrm{mw} . e . \mathrm{a}^{-1}$ and $-0.0667 \pm 0.0033 \mathrm{mw}$. e. $\mathrm{a}^{-1}$ respectively. Charity and Temnikow lie on the lee side of the Antarctic Peninsula ridge, and Stephenson Nunatak lies on the lee side of Alexander Island, so this parameter could be related to a

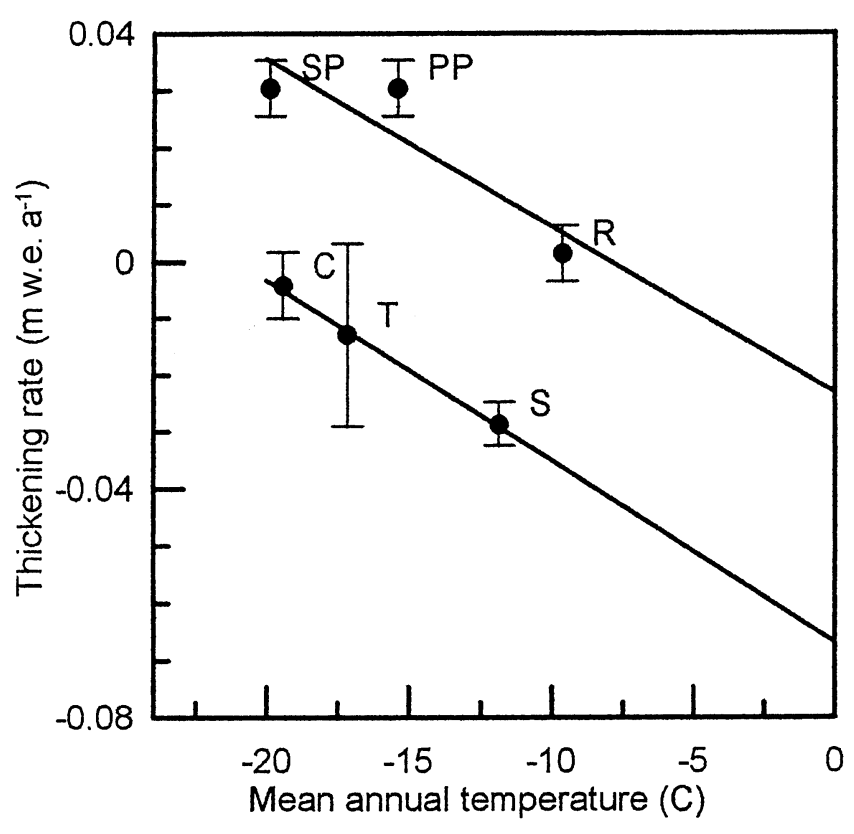

Fig. 9. Thickening rate from 1986 to 1992/93 as a function of mean annual temperature for St Pancras (SP), Puppis Pikes (PP), Rowley Corridor (R), Charity (C), Temnikow ( T) and Stephenson Nunatak $(S)$.

process which depends on position with respect to a topographic barrier (e.g. transport of blowing snow).

\section{Regional relationships}

In order to estimate changes in mass balance over the Antarctic Peninsula region as a whole, we need to use the profile data to develop a relationship between surface height changes and regional accumulation and temperature records. To do this we first define the site-corrected thickening rate, $\theta^{*}$, by the expression

$$
\theta^{*}=\theta+0.003 \mathrm{~m} \text { w.e. } \mathrm{a}^{-1} \mathrm{~K}^{-1} \mathrm{~T}_{\mathrm{m}}-\theta_{0} .
$$

This variable represents a thickening rate in which the effects of spatial variations in accumulation and temperature over the region have been removed so that all the profile data can be used together to investigate the effect of temporal changes. We have had to assume that the parameters used in Equation (3) derived from spatial variation

Table 4. Thickening rates and regional parameters

\begin{tabular}{|c|c|c|c|c|c|}
\hline Site & $\begin{array}{r}\text { Period } \\
\left(t_{1}, t_{2}\right)\end{array}$ & $\begin{array}{l}\text { Thickening rate } \\
\theta \\
\text { m w.e. } \mathrm{a}^{-1}\end{array}$ & $\begin{array}{l}\text { Site-corrected thickening rate } \\
\qquad \theta^{*} \\
\text { m w.e. } \mathrm{a}^{-1}\end{array}$ & $\begin{array}{l}A_{\mathrm{m}}\left(t_{1}, t_{2}\right) \\
\text { m w.e. } \mathrm{a}^{-1}\end{array}$ & $\begin{array}{r}B_{\mathrm{m}}\left(t_{1}, t_{2}\right) \\
\text { degree-days a }^{-1}\end{array}$ \\
\hline Puppis Pikes & 1986/93 & $0.0304 \pm 0.0049$ & $0.0075 \pm 0.0049$ & 0.953 & 43.8 \\
\hline St Pancras & 1986/93 & $0.0304 \pm 0.0049$ & $-0.0063 \pm 0.0049$ & 0.953 & 43.8 \\
\hline Rowley & 1976/86 & $0.0654 \pm 0.0035$ & $0.0595 \pm 0.0035$ & 0.964 & 17 \\
\hline Charity & 1986/92 & $-0.0042 \pm 0.0060$ & $0.0044 \pm 0.0060$ & 0.953 & 43.8 \\
\hline Temnikow & 1976/80 & $-0.0049 \pm 0.0105$ & $0.0106 \pm 0.0105$ & 0.933 & 4 \\
\hline Temnikow & $1980 / 86$ & $0.0081 \pm 0.0088$ & $0.0235 \pm 0.0088$ & 0.953 & 25.6 \\
\hline Temnikow & 1986/93 & $-0.013 \pm 0.0161$ & $0.0025 \pm 0.0161$ & 0.953 & 43.8 \\
\hline Stephenson & 1985/93 & $-0.0287 \pm 0.0039$ & $0.0027 \pm 0.0039$ & 0.953 & 43.8 \\
\hline Moraine Corrie & $1972 / 86$ & $0.1371 \pm 0.1737$ & & 0.934 & 25.4 \\
\hline Moraine Corrie & 1986/93 & $-0.393 \pm 0.0914$ & & 0.953 & 43.8 \\
\hline Moraine Corrie & 1993/95 & $1.0054 \pm 0.2102$ & & & 4.9 \\
\hline
\end{tabular}


over the period 1986-92/3 can be applied over the whole of the period 1972-98. The resulting site-corrected rates are shown in Table 4.

An accumulation time series $A_{\mathrm{t}}$ from an ice core taken at Gomez Nunatak (see Fig. 1) has been chosen to represent temporal changes in regional accumulation. The record runs from 1943 to 1992, so values are not available for the two last periods of survey for Moraine Corrie. The accumulation record from the Dyer Plateau ice core, which was also taken in the region (see Fig. 1), ends in 1988 so would not be suitable.

$$
B_{t}=0.85 R_{t}-77.4(\text { degree-days }) \mathrm{a}^{-1} .
$$

The first choice of a second series to represent temporal changes in the regional energy available for melt would be the degree-days per annum at Fossil Bluff, the nearest station to the profile sites. However, the air temperature at Fossil Bluff has not been measured during the winter since 1970/ 71 and the summer record is sporadic (Harangozo and others, 1997). The Fossil Bluff degree-day record is therefore not complete. For this reason an empirical equation is used to convert $R_{t}$, the degree-day record from Rothera, (which is reliable) into a suitable regional series $B_{t}$ for energy available for melt. The parameters of this equation have been determined by regression of measured degree-days per annum at Fossil Bluff on $R_{t}$ and are updated from the values given by Morris (1999) by the addition of meteorological data from 1996-2000. Regression of $B_{t}$ against $A_{t}$ gives a correlation coefficient of $r^{2}=0.001(n=21) . B_{t}$ is therefore a good choice for a second regional variable because it is not correlated with accumulation at Gomez.

Table 4 shows the mean accumulation at Gomez over the periods between surveys, $A_{\mathrm{m}}\left(t_{1}, t_{2}\right)$. There were two periods with the same value of mean accumulation: 197580 and 1980-86. However, the mean energy available for melt $B_{\mathrm{m}}\left(t_{1}, t_{2}\right)$, also shown in Table 4 , was not the same over the two periods. This allows the effects of the two regional variables to be separated at the one site where measurements were made over both periods, namely Temnikow. At constant $A_{\mathrm{m}}$, thickening rate $\theta^{*}$ decreases in response to increasing $B_{\mathrm{m}}$ by $1.2 \mathrm{~mm}$ w.e. ${ }^{\circ} \mathrm{Cd} \mathrm{d}^{-1}$. The intercept, $B_{0}=32.6$ degree-days $\mathrm{a}^{-1}$, a few degrees less than the mean value of $B_{t}$ averaged over the last 30 years, $B^{*}=35.2$ degree-days $\mathrm{a}^{-1}$. In other words, at the altitude of Temnikow (1600 m a.s.l.) the energy available for melt is reduced to a few degree-days $a^{-1}$ on average. Smith and others (1998) quote degree-day factors in the range 0.3$5.7 \mathrm{~mm}$ w.e. per local degree-day for Rothera Point and 1.9$15.0 \mathrm{~mm}$ w.e. per local degree-day for Spartan Glacier. The value for the sensitivity to $B_{\mathrm{m}}$ derived from the Temnikow surveys is therefore quite reasonable.

With the assumption that this value can be applied to all sites, the thickening rate can be corrected for the effect of melt using the equation

$$
\theta^{1}=\theta^{*}+0.0012 \mathrm{~m} \text { w.e. }{ }^{\circ} \mathrm{Cd}^{-1} B_{\mathrm{m}} .
$$

Figure 10 shows $\theta^{1}$ as a function of $A_{\mathrm{m}}$. The best straight line has a gradient of $2.04 \pm 0.21$ and $\theta^{1}=0$ when $A_{\mathrm{m}}=$ $0.928 \pm 0.003 \mathrm{mw} . \mathrm{e} . \mathrm{a}^{-1}$ which is similar to the mean annual accumulation at Gomez Nunatak over the last 30 years, $A^{*}=0.937 \mathrm{~m}$ w.e. $\mathrm{a}^{-1}$. In other words, the corrected thickening at all sites increases when the mean accumulation at Gomez Nunatak over the period is greater than the long-term mean, and decreases when it is less.

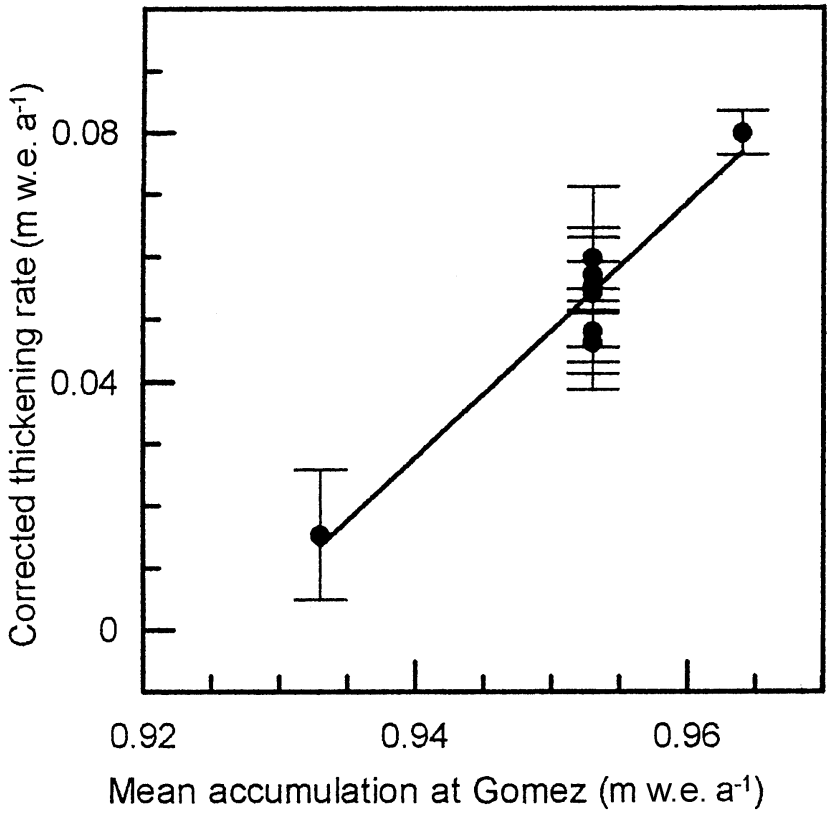

Fig. 10. Thickening rate for all sites and periods, corrected for local site temperature and regional energy available for melt, as a function of mean accumulation at Gomez Nunatak.

Although the individual terms of the local accumulation series $a_{t}$ are not correlated with $A_{t}\left(r^{2}<0.1\right.$ for all sites except for Rowley Corridor with $r^{2}=0.5$ ), this does not mean that $a_{\mathrm{m}}\left(t_{1}, t_{2}\right)$, the mean over the period $t_{1}-t_{2}$, is independent of $A_{\mathrm{m}}$. Averaging over several years improves the correlation of records from ice cores in the Antarctic Peninsula region; for example, taking a 5 year running mean increases the correlation between the Dyer Plateau and Gomez icecore accumulations from $r^{2}=0.29$ to $r^{2}=0.61$.

Nevertheless, the regional variables $A_{\mathrm{m}}$ and $B_{\mathrm{m}}$ should not be regarded as separate proxies for local accumulation and local degree-days (which may well not be independent climatic variables). Each local variable can be a function of both the independent regional variables, although the local accumulation should be most dependent on $A_{\mathrm{m}}$ and the local degree-days most dependent on $B_{\mathrm{m}}$.

This point is relevant to the observations at Moraine Corrie. Figure 11 shows the thickening rate $\theta$ can be represented as a linear function of $B_{\mathrm{m}}$. However, $B_{\mathrm{m}}$ is not simply a proxy for degree-days at Fossil Bluff (adjacent to Moraine Corrie). For one period (1993-95) the mean number of degree-days per year at Fossil Bluff is 40.48 , whereas $B_{\mathrm{m}}=$ 4.94 degree-days $\mathrm{a}^{-1}$. Otherwise the correlation is good $\left(r^{2}=0.95\right.$ for the five other periods over which various profiles were measured). When there is a cold summer temperature at Rothera but not at Fossil Bluff, as in 1993/94, this is an indication of a different airflow pattern over the Antarctic Peninsula. If this produces an anomalously large local accumulation, the local energy available for melt is expended on removing this snow cover rather than melting ice from the glacier surface. This would explain why the thickening rate at Moraine Corrie is large and positive for 1993-95. As suggested by Morris (1999), the upward velocity of the ice is not offset by the normal amount of summer melt. Thus we consider that the regional variable $B_{\mathrm{m}}$ influences both local degree-days and local accumulation rate at Moraine Corrie. Unfortunately, the value of $A_{\mathrm{m}}$ for 1993-95 will not be known until an extension core is collected at Gomez Nunatak, but all the data we have so far suggest $A_{\mathrm{m}}$ and 


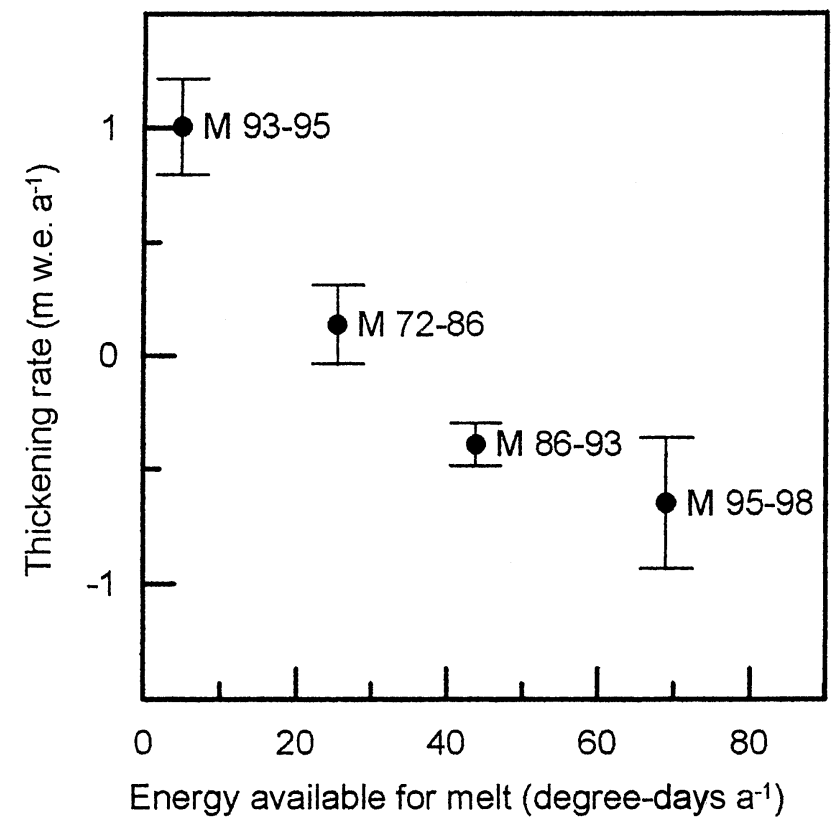

Fig. 11. Thickening rate at Moraine Corrie as a function of regional energy available for melt, estimated using the Rothera air-temperature record.

$B_{\mathrm{m}}$ are not correlated, so the hypothetical increased accumulation should be local to the region around Moraine Corrie on the east side of Alexander Island.

The sensitivity to $B_{\mathrm{m}}$ is $-0.0257 \pm 0.0055 \mathrm{~m}$ w.e. ${ }^{\circ} \mathrm{Cd}^{-1}$. Thus the regional degree-day factor is $25.7 \pm 5.5$ mmw.e. ${ }^{\circ} \mathrm{Cd}^{-1}$. A local degree-day factor of $33 \pm 8$ mm w.e. ${ }^{\circ} \mathrm{C} \mathrm{d}^{-1}$ was obtained previously by Morris (1999) using the 1986, 1993 and 1995 profile data. The addition of 1998 data and a different regional approach have produced a better fit, which includes the 1972-86 data point. This point was excluded from the Morris (1999) analysis because the 1972 survey was made at the end of winter rather than the end of summer, so the thickening rate for 1972-86 could be a significant underestimate. However, Figure 11 does not indicate that this point is anomalous, so it has been retained.

\section{IMPLICATIONS FOR SEA-LEVEL RISE}

Combining the results of the previous section gives an expression for thickening rate

$$
\begin{aligned}
\theta= & (2.04 \pm 0.21)\left(A_{\mathrm{m}}-A^{*}\right) \\
& -\left[0.0012 \mathrm{~m} \text { w.e. }{ }^{\circ} \mathrm{Cd}^{-1}\right]\left(B_{\mathrm{m}}-B_{0}\right) \\
& -0.003 \mathrm{~m} \text { w.e. } \mathrm{a}^{-1} \mathrm{~K}^{-1} T_{\mathrm{m}}+\theta_{0}
\end{aligned}
$$

where $B_{0}$ is a site-related constant. We now use Equation (6) to estimate the effect of a general $1{ }^{\circ} \mathrm{C}$ warming on sea-level rise. Suppose that the warming is from current climatic conditions, and that the increase in mean annual temperature occurs equally in summer and winter. Since the mean value of $B_{\mathrm{m}}$ averaged over the last 30 years is $\approx 35$ degree-days $\mathrm{a}^{-1}$, its response to a temperature rise $\Delta T_{\mathrm{m}}=1^{\circ} \mathrm{C}$ is estimated as $\partial B_{\mathrm{m}} / \partial T_{\mathrm{m}} \approx 40$ degree-days $\mathrm{a}^{-1} \mathrm{~K}^{-1}$. Assuming a modest $3 \%$ rise in precipitation per degree at Gomez Nunatak (at the lower end of the range of 3-9\% found in the literature) the response of $A_{\mathrm{m}}$ is estimated as $\partial A_{\mathrm{m}} / \partial T_{\mathrm{m}} \approx 0.03 A^{*} \mathrm{~K}^{-1}=0.028 \mathrm{~m}$ w.e. $\mathrm{a}^{-1} \mathrm{~K}^{-1}$. Since the factors which control $\theta_{0}$ are unknown, we neglect $\partial \theta_{0} / \partial T_{\mathrm{m}}$. However, if $\theta_{0}$ is connected to wind speed for example, this factor may not be negligible.

The thickening-rate sensitivity then becomes $\partial \theta / \partial T_{\mathrm{m}} \approx$ $0.0061 \mathrm{~m}$ w.e. $\mathrm{a}^{-1} \mathrm{~K}^{-1}$. This may be compared to the sensitivities of ice-sheet mass balance to temperature for Antarctica given by Church and others (2001) as part of the third assessment report of the Inter-governmental Panel on Climate Change (IPCC). In their table 11.13, mass-balance sensitivities are given in terms of millimetres of sea-level rise per year per degree rise in surface air temperature averaged over the whole of the continent. They range from -0.11 to $-0.33 \mathrm{~mm} \mathrm{a}^{-1} \mathrm{~K}^{-1}$ for the various atmospheric- oceanic general circulation model experiments following the IS92a scenario. Assuming values of $3.62 \times 10^{8} \mathrm{~km}^{2}$ for the oceanic area and $12.37 \times 10^{6} \mathrm{~km}^{2}$ for the area of the continent, this translates to a range from 0.0032 to $0.0097 \mathrm{~m}$ w.e. $\mathrm{a}^{-1} \mathrm{~K}^{-1}$. The sensitivity for the Antarctic Peninsula which we have derived from observations lies in the middle of this range.

Global circulation model (GCM) predictions of climate change over the Antarctic Peninsula are known to be imprecise because of the difficulty of representing the topography on the model gridscale. It is therefore helpful to have confirmation from the level line data that the sensitivities found for the continent as a whole are of the right order for the Peninsula region.

For the first degree rise in temperature from current climatic conditions (i.e. conditions averaged over the last 30 years $)$ the sensitivity $\left(\partial \theta / \partial A_{\mathrm{m}} \partial A_{\mathrm{m}} / \partial T_{\mathrm{m}}\right)$ is $0.057 \mathrm{mw}$.e. $\mathrm{a}^{-1} \mathrm{~K}^{-1}$ and is greater than the sensitivity $\left(\partial \theta / \partial B_{\mathrm{m}} \partial B_{\mathrm{m}} / \partial T_{\mathrm{m}}+\partial \theta / \partial T_{\mathrm{m}}\right)$ of $0.051 \mathrm{~m}$ w.e. $\mathrm{a}^{-1} \mathrm{~K}^{-1}$. Since one is positive and one negative, they can be referred to as the "accumulation sensitivity" and the "ablation sensitivity" provided that it is understood that they involve regional not local variables. At 3\% rise in precipitation per degree, ablation sensitivity starts to dominate when $B_{t} \approx 50$ degree-days $\mathrm{a}^{-1}$. This is equivalent to a value of $R_{t} \approx 150$ degree-days $\mathrm{a}^{-1}$ which occurs when the mean annual temperature at Rothera is around $-5^{\circ} \mathrm{C}$. Over the last 5 years (1996-2000) the mean temperature at Rothera has been $-3.6^{\circ} \mathrm{C}$, so the implication is that a $1^{\circ} \mathrm{C}$ warming from recent conditions would reduce thickening or enhance thinning at the profile sites.

Thinning of the ice cap does not necessarily translate directly to a change in sea level. For sites where there is no lateral runoff, any melt is refrozen within the snowpack. Temperature-enhanced densification also produces thinning, which does not lead directly to sea-level rise. Summer lateral runoff has been observed at Moraine Corrie and Rowley Corridor and there are supraglacial streams not far from the Stephenson Nunatak profile. But for the areas with $T_{\mathrm{m}} \leq-11^{\circ} \mathrm{C}$ the contribution to sea-level rise is governed by accumulation alone.

We have shown that height changes in the mid-peninsula region lying between Rothera station and Gomez Nunatak can be explained in terms of the accumulation at Gomez and degree-days at Rothera. These regional variables represent changing patterns of advection of moisture into the Antarctic Peninsula region as well as the simple thermodynamic link between changes in air temperature and water-vapour content (the Clausius-Clapeyron relation). They are useful indicators of climate change in the region and should therefore be monitored in the future. Fortu- 
nately this should not be difficult. Air temperature at Rothera will continue to be recorded as long as the station remains occupied; Gomez Nunatak is relatively easy to access and the accumulation record can be updated by taking shallow ice cores every $15-25$ years.

Frolich (1992) has divided the Antarctic Peninsula into catchments and estimated total surface mass balance for each. His mid-peninsula catchments $\mathrm{H}^{\prime}-\mathrm{I}$ and $\mathrm{I}^{\prime \prime}-\mathrm{J}$ cover an area of $172.6 \times 10^{3} \mathrm{~km}^{2}$. In terms of sea-level rise, the sensitivity to a $1^{\circ} \mathrm{C}$ warming from the present climatic conditions for this region can be estimated as $-0.003 \pm 0.001 \mathrm{~mm} \mathrm{a}^{-1} \mathrm{~K}^{-1}$. The area of the whole of the Antarctic Peninsula (catchments $\mathrm{H}^{\prime}-\mathrm{J}$ ) is $330 \times 10^{3} \mathrm{~km}^{2}$ (Frolich, 1992). If the mid-peninsula sensitivities can be applied more widely this leads to a sensitivity for the whole region of $-0.006 \pm 0.002 \mathrm{~mm} \mathrm{a}^{-1} \mathrm{~K}^{-1}$ in terms of sea-level rise.

The real importance of the Antarctic Peninsula response derives from the fact that with a small climate warming (i.e. if recent temperature conditions persist) ablation sensitivity becomes greater than accumulation sensitivity and, if run-off is possible, the area with $T_{\mathrm{m}}>-11^{\circ} \mathrm{C}$ can contribute to sea-level rise.

Using the sea-level isotherms and lapse rates determined by Reynolds (1981), Morris and Mulvaney (1996) estimated that an area of some $20000 \mathrm{~km}^{2}(2 \%)$ of the Antarctic Peninsula had a mean annual surface temperature warmer than $-11^{\circ} \mathrm{C}$. They used a conservative estimate of ablation sensitivity of $0.25 \mathrm{~m} \mathrm{a}^{-1} \mathrm{~K}^{-1}$ which led to $0.012 \mathrm{~mm} \mathrm{a}^{-1} \mathrm{~K}^{-1}$ of sea-level rise. We now have more confidence in the ablation sensitivity determined at Moraine Corrie of $25.7 \pm 5.5 \mathrm{~mm}$ w.e. ${ }^{\circ} \mathrm{Cd}^{-1}$. With a warming of 30 degree-days $\mathrm{a}^{-1} \mathrm{~K}^{-1}$ this suggests an upper bound of $1.3 \pm 0.3 \mathrm{~m} \mathrm{a}^{-1} \mathrm{~K}^{-1}$ which leads to $0.07 \pm 0.02 \mathrm{~mm} \mathrm{a}^{-1} \mathrm{~K}^{-1}$ of sea-level rise.

Thus we conclude that, if recent temperature conditions persist, ablation in the Antarctic Peninsula region could offset the effects of increased precipitation and reduce the contribution of Antarctica to sea-level fall by up to $15 \%$.

\section{ACKNOWLEDGEMENTS}

The work described in this paper was supported in part by the European Union-funded project "The Contribution of Antarctic Peninsula Ice to Sea Level Rise". We are grateful to D. Routledge, A. Smith and F. Lyman for assistance with the fieldwork, to the U.K. Natural Environment Research Council Isotope Geochemistry Laboratory for isotope analysis and to G. Hamilton and another referee for helpful comments on an earlier version of this paper.

\section{REFERENCES}

Church, J. A. and 7 others. 2001. Changes in sea level. In Houghton, J. T. and 7 others, eds. The scientific basis: contribution of Working Group I to the third assessment report of the Intergovernmental Panel on Climate Change. Cambridge, Cambridge University Press. Intergovernmental Panel on Climate Change, World Meteorological Organization/United Nations Environmental Program, 639-694.

Fox, A. J. and A. P. R. Cooper. 1998. Climate-change indicators from archival aerial photography of the Antarctic Peninsula. Ann. Glaciol., 27, 636-642.

Frolich, R. M. 1992. The surface mass balance of the Antarctic Peninsula ice sheet. In Morris, E. M., ed. The contribution of Antarctic Peninsula ice to sea level rise. Cambridge, British Antarctic Survey, 3-9. (Ice and Climate Special Report 1.)

Hamilton, G. S., I. M. Whillans and P. J. Morgan. 1998. First point measurements of ice-sheet thickness change in Antarctica. Ann. Glaciol., 27, $125-129$.

Harangozo, S. A., S. R. Colwell and J. C. King. 1997. An analysis of a 34year air temperature record from Fossil Bluff $\left(71^{\circ} \mathrm{S}, 68^{\circ} \mathrm{W}\right)$, Antarctica. Antarct. Sci., 9(3), 355-363.

Hurst, H. E., R. P. Black and Y. M. Simaika. 1965. Long-term storage: an experimental study. London, Constable and Co.

King, J. C. 1994. Recent climate variability in the vicinity of the Antarctic Peninsula. Int. 7. Climatol., 14(4), 357-369.

Morris, E. M. 1999. Surface ablation rates on Moraine Corrie Glacier, Antarctica. Global Planet. Change, 22(1-4), 221-231.

Morris, E. M. and R. Mulvaney. 1996. Recent changes in surface elevation of the Antarctic Peninsula ice sheet. Z. Gletscherkd. Glazialgeol., 31, Part 1, 1995, 7-15.

Morris, E. M. and D. G. Vaughan. 1994. Snow surface temperatures in West Antarctica. Antarct. Sci., 6(4), 529-535.

Peel, D. A. 1992. Ice core evidence from the Antarctic Peninsula region. In Bradley, R. S. and P. D. Jones, eds. Climate since A.D. 1500. London and New York, Routledge, 549-571.

Reynolds, J. M. 1981. The distribution of mean annual temperatures in the Antarctic Peninsula. Br. Antarct. Surv. Bull., 54, 123-133.

Richardson, N. A. 1986. Glacier fluctuation studies 1985-86. Cambridge, British Antarctic Survey. (BAS Field Report R/1985-86/S5-S12.)

Smith, A. M., D. G. Vaughan, C. S. M. Doake and A. G. Johnson. 1998. Surface lowering of the ice ramp at Rothera Point, Antarctic Peninsula, in response to regional climate change. Ann. Glaciol., 27, 113-118.

Turner, J., S. R. Colwell and S. A. Harangozo. 1997. Variability of precipitation over the coastal Antarctic Peninsula from synoptic observations. 7. Geophys. Res., 102(D12), 13,999-14,007.

Wingham, D. J. 2000. Small fluctuations in the density and thickness of a dry firn column. f. Glaciol., 46(154), 399-411. 